\title{
Perempuan Minang Merantau
}

\author{
Wenhendri $^{1)}$, Yusril $^{2)}$, Ediwar $^{3)}$ \\ ${ }^{12) 3)}$ Program Pascasarjana ISI Padangpanjang
}

Jl. Bahder Johan Guguk Malintang, Padang Panjang-Kota Padang Panjang, Sumatera Barat 27118

Email : wensikumbang1@gmail.com ${ }^{1)}$,yusril@yahoo.com ${ }^{2)}$, ediwar@yahoo.com ${ }^{3)}$

\begin{abstract}
Designing theatrical work of female migration scripts, inspired by the phenomenon of social change in the Minangkabau community, which tells the story of minangkabau women who go abroad. Social change has and will continue to occur, it may occur as a development from whitin society itself. So every Minangkabau person must know the kinship arrangement with each other other, in order to understand his own place and position. Exploring the value of tradition and preserving the noble values of the nation are the main ideas that will be poured in this work, namely modern theater that cannot be separated from the text elements of a literary work in a complete composition, dialogs, moods, spectacles, backgrounds, themes and figures that bintolakan randai. Randai pattern is meant here, the motion, dialogue, gurindam, character and story. In the creation of theater art, writers and directors do randai pattern as traditional theater Minangkabau mate with the nature of modern theater, in which the players in the women's migration script must be clever, shrewd, silat, ekting and dialogue.
\end{abstract}

Keywords : Theater Migration of Women is a Modern Theater

\begin{abstract}
Abstrak
Perancangan karya seni teater naskah lakon Migrasi Perempuan, terinspirasi dari fenomena perubahan sosial masyarakat Minangkabau, yang bercerita tentang perempuan Minangkabau yang pergi merantau. Perobahan sosial telah dan akan terus terjadi, mungkin terjadi sebagai perkembangan dari dalam masyarakat itu sendiri. Maka setiap orang Minangkabau wajib mengetahui susunan kekerabatan satu dengan yang lainnya, supaya dapat memahami tempat dan kedudukannya sendiri. Menggali nilai tradisi dan melestarikan nilai-nilai luhur bangsa adalah gagasan utama yang akan dituangkan dalam kekaryaan ini, yaitu teater modern yang tidak terlepas dari unsur-unsur teks suatu karya sastra dalam susunan yang utuh; (dialog, mood, spektakel, latar, tema dan tokoh) yang berpolakan randai. Polapola randai yang dimaksud disini adalah, adanya gerak, dialog, gurindam, penokohan dan cerita. Dalam penciptaan karya seni teater, penulis sekaligsus sutradara melakukan pola-pola randai sebagai teater tradisional Minangkabau mengawinkan dengan hakekat teater modern, yang mana para pemain dalam naskah lakon Migrasi Perempuan harus pandai berdendang, bergore, gerak silat, akting dan dialog.
\end{abstract}

Kata kunci : Teater “Perempuan Minang Merantau”, randai, teater, modern 


\section{Pendahuluan}

Adat Minangkabau sebagai salah satu bagian dari kebudayaan nasional diwarisi dari nenek moyang dahulunya bukanlah merupakan pengetahuan yang dikodivikasikan sebagaimana layaknya pengetahuan sosial lainnya didunia. Adat di Minangkabau diterima secara turun temurun dari mulut kemulut (Warih samo dijawek, Tutua samo didanga) melalui pepatah-petitih, mamang, bidal, pantun dan gurindam adat, yang berkembang yang menjadi adat basandi syara', syara'basandi kitabullah yang artinya bahwa aturanaturan adat Minangkabau takhluk dibawah syariat Islam (adat berdasarkan agama, agama berdasarkan kitab Allah SWT), menempatkan perempuan sebagai pemimpin masyarakatnya sebagai sebutan Bundo Kanduang.

Kompleknya fungsi dan peranan Bundo Kanduang digambarkan dalam ungkapan yang berbunyi: Bundo kanduang nan gadang basa batuah, umbun puruak dalam nagari, kapai tampaik batanyo, kapulang tampaik babarito, kok hiduik tampaik banaza, kok mati tampaik baniaik, ka unduang-unduang ka Madinah, ka payuang panji ka sarugo (Bundo Kanduang yang agung besar batuah, umbun pura dalam nagari, ketika pergi tempat bertanya, ketika pulang tempat beberita, jika hidup tempat bernazar, jika mati tempat berniat, sebagai pengayom kemadinah, sebagai payung panji ke sorga), dan menempatkan kedudukan perempuan Minangkabau pada posisi sentral.

Dalam budaya Minangkabau perempuanlah pemilik seluruh kekayaan rumah, anak, suku bahkan kaummya, citra perempuan diperankan secara sempurna dengan posisi sentral sebagai ibu. Perempuan adalah tiang negeri, limpapeh minang, ranah pagaruyuang (pilar utama Minangkabau, tanah Pagaruyung). Posisi ini adalah penghormatan mulia sorga terletak dibawah telapak kaki ibu (AL-Hadist). Secara adat, prinsip kekerabatan adat masyarakat Minangkabau adalah matrilineal yang mengatur hubungan kekerabatan melalui garis ibu, dimana seorang anak akan mengambil suku ibunya. Garis keturunan ini mempunyai arti pada penerusan harta warisan, seorang anak akan memeperoleh warisan menurut garis ibu. Warisan yang dimaksud adalah berupa harta peninggalan yang sudah turun temurun menurut garis ibu. Hartabwarisan disebut pusaka tinggi dan pusaka rendah. Pusaka tinggi adalah harta yang diwarisi dari ibu secara turun temurun, sedangkan pusaka rendah adalah warisan dari hasil usaha ibu dan bapak selama mereka terikat perkawinan.

Sebagai konsekuensi dari sistim pewarisan pusaka tinggi, setiap warisan akan jatuh pada anak perempuan, anak laki-laki tidak mempunyai hak memiliki hanya hak mengusahakan, sedangkan anak perempuan mempunyai hak memiliki sampai pula diwariskan pada anak perempuannya. Anak laki-laki hanya boleh mengambil dari hasil harta warisan sesuai dengan usahanya, tetapi tidak dapat mewariskan kepada anaknya. Kalau ia meninggal, maka harta itu akan kembali kepada ibunya atau kepada adik perempuan dan kemenakannya (Yunus, 1990: 39-40).
Seiring dengan perkembangan zaman dan pengaruh era globalisasi perubahan sosial telah dan akan terus terjadi, mungkin terjadi sebagai perkembangan dari dalam masyarakat itu sendiri, mungkin pula terjadi karena persentuhan dengan masyarakat lain, kebudayaan lain ataupun diatur oleh pemerintah. Ketika perubahan sosial itu terjadi, ada aspek lain dalam masyarakat itu yang turut berubah, antara lain seni dan budaya.

Hal ini juga diungkapkan oleh Haviland dalam Sahrul N, (2005:1) yang menjelaskan bahwa kebudayaan pada suatu waktu akan berubah. Setidaknya ada dua hal yang menjadi penyebab perubahan kebudayaan. Pertama adalah terjadinya perubahan lingkungan yang dapat menuntut perubahan kebudayan yang bersifat adaptif. Kedua terjadinya kontak dengan bangsa lain yang mungkin menyebabkan diterimanya kebudayaan asing sehingga terjadilah perubahan dalam nilai-nilai dan tata kelakuan yang ada. Kemampuan berubah merupakan sifat yang penting dalam kebudayaan manusia.

Berdasarkan penjelasan diatas fenomene-fenomena perubahan ini juga dapat dilihat dari fungsi dan peran perempuan dalam suatu suku di Minangkabau yang mulai memudar citranya. Karena biasanya budaya merantau dilakukan oleh laki-laki Mianangkabau, meninggalkan kampung halaman untuk mencari kekayaan, ilmu pengetahuan, dan kemasyuran, mulai diperhatikan pada permulaan abad ke-20. Lekkerkerker, dalam bukunya yang diterbitkan tahun 1916, mencoba menjelaskan apa yang menyebabkan gejala ini. Dia berpendapat bahwa penyakit merantau berhubungan erat dengan kedudukan laki-laki dalam masyarakat Minangkabau. Ia melihat bahwa merantau adalah sebuah cara bagi kaum laki-laki di Minangkabau untuk melarikan diri dari matriarchy (kekuasan kaum wanita) secara sadar atau tidak, seorang lelaki Minangkabau selalu berusaha mencari sebuah tempat di mana dia dapat menemui kebebasannya dan kepribadiannya.

Pertunjukan Perempuan Minang Merantau terinspirasi dari fenomena dari perubahan sosial masyarakat Minangkabau. Adapun peristiwa yang hadir dalam penceritaan tentang pergeseran dan fungsi seorang perempuan minang merantau yang membawa perubahan pada sikap prilaku perempuan di Minangkabau yang menganut system matrilineal.

\section{Pembahasan}

Seni teater merupakan seni yang komplek. Kompleksitas teater tersebut merupakan gabungan dari harmonisasi seni rupa, seni musik, seni tari dan seni peran. Unsur-unsur tersebut menyatu dalam jalinan kerja kreator yang kemudian dapat dinikmati oleh penonton.

Sebagai seni yang kompleks, teater sarat dengan berbagai kepentingan, untuk kepentingan transpormasi ide teater berguna sebagai media menyampaikan gagasan yang dapat memperbaiki nilai sosial budaya masyarakat, untuk kepentingan penyutradaraan menjadikan teater sebagai alat pemberdayaan sutradara, dan untuk kepentingan menghibur menjadikan teater sebagai media 
ekspresi menetapkan teater sebagai media ekspresi kesenimanan secara total.

Kreativitas sutradara bersumber dari naskah lakon, karena naskah lakon merupakan bahan dasar sebuah pementasan. Sebagai bentuk ungkapan pernyataan perasaan penulis, di dalam naskah lakon terdapat nilainilai pengalaman umum dan nilai estetis. Naskah lakon berfungsi member inspirasi kepada seniman penafsir.

Sutradara sebagai seniman penapsir diharapkan mampu menghayati naskah drama dengan kecakapan dan daya imajinasinya. Sutradara harus mampu menangkap pesan dan tema naskah, nada dan suasana drama secara menyeluruh, dan juga harus dipahami misteri yang tersembunyi dibalik naskah lakon, semua itu harus harus dihayati dengan baik oleh sutradara.

Mewujudkan pementasan dan kreatifitas sutradara, untuk dapat memberi peluang dalam mengembangkan ide, maka perlu dipilih naskah lakon yang memiliki kekuatan artistik serta tokoh-tokoh yang tegas sehingga memungkinkan untuk melakukan pengembangan. Berdasarkan itu penulis/sutradara, memilih naskah lakon Perempuan Minang Merantau untuk dipentaskan. Naskah lakon Perempuan Minang Merantau memiliki keunggulan tersendiri. Keunggulan tersebut ditemukan pada ; 1) latar kebudayaan yang jelas yaitu Minangkabau, 2) Konflik-konflik yang dihadirkan bersifat universal yaitu berangkat dari realita sosial masyarakat yang jelas, 3) Muatan-muatan yang mempunyai makna besar, yang kurang lebih bertumpu pada persoalan Perempuan Minang Merantau pada hari ini.

Lakon Perempuan Minang Merantau yang penulis tapsirkan ini, berbicara tentang seorang perempuan Minangkabau pergi merantau, maka terlihatlah perubahan sosial dan sistem yang ada dalam masyarakat Minangkabau hari ini.

Faktor pendidikan telah terbukti menjadi factor pendorong yang mampu mendorong yang lainnya untuk ikut merantau, karena setiap pelajar perempuan yang pergi merantau membukakan jalan bagi pelajar berikutnya untuk melakukan hal yang sama. Cerita-cerita tentang keberhasilan yang terjadi dalam pencapain pendidikan oleh para pelajar perempuan yang dirantau mendorong yang muda-muda untuk mengikuti jejak langkahnya. Para lulusan perempuan yang muda-muda dirantau ini biasanya mereka tidak balik kekampuang, malahan sebaliknya mereka menetap dirantau sambil bekerja dan bahkan banyak dari mereka menjadi orang penting. Hal ini sudah cukup untuk membangkitkan keinginan anak-anak muda yang perempuan Minangkabau yang masih berada dikampung untuk mengikuti jejaknya.

Akibat semakin mahalnya kebutuhan hidup seharihari, akhirnya perempuan Minangkabau memeutuskan untuk pergi merantau. Salah satu alasannya karena dikampung sawah dan ladang sudah banyak yang tergadai dan terjual yang bertukar fungsi menjadi perumnas atau bangunan gedung-gedung pencakar langit. Ditambah lagi keinginan mengikuti perkembangan modern dan gaya hidup yang konsumtif (yang menonjolkan kemewahan, kesenangan dan berfoya-foya serta menghamburkan uang).

Teknologi informasi dan komunikasi hari ini sangat memudahkan perempuan Minangkabau untuk melihat perkembangan yang terjadi di dunia luar, begitu juga dengan mudahnya mereka berkomunikasi dan belajar melalui internet.

Merantaunya kaum perempuan di Minangkabau mempengaruhi sosial, budaya, pendidikan dan ekonomi dimasyarakat Minangkabau. Seiring dengan perkembangan zaman dan pengaruh globalisasi perubahan sosial telah dan akan terus terjadi, mungkin terjadi sebagai perkembangan dari dalam masyarakat itu sendiri, mungkin pula terjadi karena persentuhan dengan masyrakat lain, kebudayaan lain ataupun diatur oleh pemerintah. Ketika perubahan sosial itu terjadi, ada aspek lain dalam masyarakat itu yang turut berubah, anatara lain seni dan budaya.

Sistem sosial Matrilineal dan hukum adat menempatkan perempuan sebagai pewaris dan pemilik sah pusaka, namun hari ini perempuan Minangkabau sudah banyak yang pergi merantau. Jadi harta pusaka sudah banyak yang digadai atau dijual karena tidak ada lagi yang menggarapnya untuk sawah dan ladang, begitu juga dengan rumah gadang sudah tidak ada penghuninya, jadi secara tak langsung harta pusaka bisa digadai atau dijual oleh seorang mamak di Minangkabau. Dengan merantaunya perempuan Minangkabau maka sawah dan ladang sudah bertukar fungsi menjadi perumahan dan gedung.

Pertunjukan Perempuan Minang Merantau, terinspirasi dari fenomena perubahan sosial masyarakat Minangkabau. Adapun peristiwa yang hadir dalam penceritaan tentang budaya merantau yang dilakukan oleh laki-laki diminangkabau sekarang sudah digantikan oleh perempuan, yang membawa perubahan pada sikap dan prilaku perempuan di Minangkabau yang menganut sistem Matrilineal.

Dari uraian diatas pertunjukan Perempuan Minang Merantau memakai 3 orang tokoh sentral untuk menyampaikan pesan pada penonton. Ketiga tokoh ini merupakan perwakilan zamannya masing-masing. Adapun tokoh yang dihadirkan (1) tokoh laki-laki yang berperan sebagai mamak, menggambarkan seorang mamak yang selalu memberi nasehat-nasehat pada kemenakan supaya jangan pergi merantau kenegeri orang karena dikampung masih banyak yang bisa dikerjakan. Ketika kemenakan ingin pergi merantau mamak hanya bisa memeberi nasehat tapi selama ini mamak tidak pernah mengajarkan masalah adat istiadat serta memperhatikan kemenakannya. Mamak tidak pernah lagi melaksanakan tugasnya sebagai mamak diranah Minangkabau. (2) Tokoh perempuan yang menjadi adik dari mamak, perempuan ini mewakili zaman sekarang, yang perempuan ini memepunyai seorang anak perempuan sudah lama ditinggal suaminya yang meninggal, perempuan ini mau menjual tanah pusaka yang gunanya untuk pergi merantau. (3) Perempuan yang baru tamat kuliah ini mewakili perannya pada zaman sekarang, karena sulitnya mencari 
kerja dikampung maka perempuan ini memutuskan untuk pergi merantau walaupun mamaknya melarang dia tetap pergi juga. Menggambarkan perempuan yang tidak mau terikat dengan aturan-aturan adat istiadat yang memebuat ruang geraknya terbatas, perempuan yang tidak mau hidup bertani dan berladang serta didapur, sumur dan kasur, tapi dia harus keluar dari rotasi ini dan masuk dalam rotasi kehidupan malam yang ada dikotakota besar sebagai perempuan penghibur untuk laki-laki yang hidung belang.

Pertunjukan Perempuan Minang Merantau ini berangkat dari idiom-idiom randai seperti gurindam (dendang, garak, sastra, penokohan) yang kehadirannya bukan hanya sebagai pelengkap tapi sebagai unsur yang penting dalam pertunjukan, yang mana dendang dan gerak sebagai penghubung adegan dan memperjelas tentang ruang dan waktu, serta memperkuat budaya yang diusung adalah Minangkabau, supaya penonton dengan mudah masuk kedalam peristiwa dan suasana yang terjadi di atas panggung.

Naskah Perempuan Minang Merantau memberikan kemungkinan keleluasaan control dalam pemilihan dan penekanan teknik serta kualitas artistik pemanggungan, dan jika kovensi mengontrol hubungan antar teknik pencitaan artistic panggung dengan harapan penonton, maka gaya menentukan secara tepat bagaimana menggunakan teknik, kualitas, serta materi kovensi.

Yudiaryani dalam bukunnya panggung Teater Dunia, (2002:359) menjelaskan ada 2(dua) gaya dalam pemanggungan, yaitu gaya presentasi dan gaya representasi. Gaya presentasi adalah gaya yang berusaha menghadirkan seluruh kenyataan keseharian di atas panggung apa adanya. Sedangkan gaya representasi merupakan keinginan seniman untuk menghadirkan panggung sebagai interpretasi seluruh formula dan unsur-unsur pemanggungan yang secara kesejarahan telah ada.

Dari uraian diatas dapat disimpulkan bahwa pertunjukan Perempuan Minang Merantau menggunakan gaya representasi dengan bentuk surialisme karena dilihat dari suasana, gerak, bunyi, pengolahan dan pemaknaan setting serta simbolis katakata yang abstrak.

Media penyampaian dalam pementasan lakon Perempuan Minang Merantau bertumpu pada kesatuan pentas, secara umum terdiri dari pementasan teater yang berawal dari sebuah naskah lakon untuk dijadikan dasar penggarapan, mewujudkan dan menuangkan ide dan gagasan penulis dalam bentuk dialog antar tokoh dan suasana-suasana yang dihadirkan konteks dengan peristiwa sosial budaya di Minangkabau.

Penokohan merupakan penjelasan karakter tokoh yang menyangkut kualitas, ciri atau sifat pribadi tokoh yang dimunculkan dalam lakon. Harymawan (1988: 25) mengatakan bahwa: karakter bisa juga disebut dengan tokoh yaitu: bahan yang paling aktif yang menjadi penggerak dalam cerita. Karakter disini adalah tokoh yang hidup bukan tokoh yang mati. Karakter itu berpribadi, berwatak sekaligus memiliki sifat-sifat karakteristik. Anirun (1998: 37) berpendapat bahwa: penokohan atau perwatakan merupan sarana untuk membedakan satu peran dengan peran yang lainnya.

Penokohan atau tokoh merupakan orang yang memegang peranan penting dalam ,menyampaikan peristiwa-peristiwa yang ingin disampaikan oleh pengarang. Tokoh dan penokohan dalam lakon menjadi wakil kesadaran dari ide pengarang. Tokoh bertugas membangun cerita melalui dialog sesuai dengan peran yang dibawakannya.

Aktor/pemeran yang dihadirkan dalam pertunjukan ini terdiri dari 3(tiga) orang tokoh, pertama, tokoh lelaki (protagonis), perwakilan dari mamak itu sendiri. Kedua, tokoh perempuan baik dari mamak itu sendiri (tokoh foil) perwakilan atau gambaran perempuan masa sekarang. Ketiga, tokoh perempuan kemenakan dari mamak (tokoh antagonis) merupakan perwakilan dari perempuan masa kini.

Ketiga tokoh dalam pertunjukan Perempuan Minang Merantau dipilih dan diperankan oleh: (1) mamak, diperankan oleh Deni, pemilihan berdasarkan kecocokan usia atau umur, jenis kelamin dan keadaan tubuh tokoh yang diperankan; (2) perempuan adik dari mamak itu sendiri, diperankan oleh Ami, pemilihan ini berdasarkan kecocokan usia atau umur, jenis kelamin, keadaan tubuh dengan tokoh yang diperankan; (3) perempuan diperankan oleh salsa, pemilihan ini berdasarkan kecocokan usia atau umur, jenis kelamin dan keadaan tubuh dengan tokoh yang diperankan.

Dalam rancangan artistik untuk menuju suatu bentuk estetika panggung yang utuh, perlu dikaji beberapa hal yang sangat mendasari suatu perancangan. Seperti yang dikatakan Kouzan dalam Rhadar panca Dahana dibuku Ideologi Politik dan Teater Modern Indinesia, menetapkan da tiga belas unit kecil tanda panggung, antara lain: kata, tone, mimic, wajah, gesture, gerak/kinesis, tata wajah (make up), tata rambut (hair style), tata busana, properti, dekor, tata lampu (ligh), music dan efek suasana (sound effect) (2000: 56).

Desain pentas (set dekorasi) adalah setting atau tata pentas yang digunakan dalam pementasan. Harymawan dalam buku Dramaturgi mengatakan bahwa: "setting pentas adalah proses penyusunan tokoh-tokoh manusia sedemikian rupa sehingga barisan kelompok yang tersusun menciptakan gambaran artistik yang berarti (1998: 47)','. Berangkat dari pendapat Harymawan ini maka naskah lakon Perempuan Minang Merantau merupakan sebuah latar belakang rumah gadang diminangkabau.

Tata cahaya merupakan salah unsur yang penting dalam pertunjukan teater. Selain berfungsi sebagai alat penerang juga berfungsi sebagai pendukung artistic dan penunjuk waktu serta pencipta suasana. Harymawan (2988: 147) mengatakan bahwa: "problem artistic dalah bagaimana kita menegaskan dan menggunakan lighting sehingga dapat merangsang emosi penonton. Dalam penciptaan suasana lakon Perempuan Minang Merantau penulis sekaligus sutradara lebih banyak menonjolkan atau memakai lampu focus zoom spot dan lampu netral atau ellipsoidal. Hal ini bertujuan memperkuat karakter tokoh di awal atau di akhir pertunjukan. 
Suasana lakon salah satunya ditentukan dengan mengatur intensitas lampu dan warna lampu yang digunakan. Terutama dalam penciptaan suasana menegangkan dan suasana hening serta membangun suasana emosional. Jenis lampu yang digunakan dalam pementasan lakon Perempuan Minang Mertau adalah lampu Part, presnel dan zoom spot.

Harymawan dalam Dramaturgi berpendapat bahwa: "Musik mempunyai peranan penting dalam teater, dengan musik penonton bertambah daya imajinasinya. Musik teater membantu para aktor membawakan makna dan warna perannya dalam adegan. Musik juga dapat dijadikan sebagai awal dan penutup adegan, sekaligus sebagai jembatan antara adegan satu dengan adegan yang lain (1998: 162)". Tata musik adalah penggunaan iringan musik untuk suasana dan menampilkan latar cerita secara utuh. Penggunaan jenis ilustrasi musik akan disesuaikan dengan atmosfir pentas yang akan penulis atau sutradara bawa dalam keadaan dan suasana masyarakat Indonesia, khususnya Minangkabau, yaitu pada zaman sekarang.

Jenis ilustrasi musik adalah penggunaan jenis alat musik tradisional dan alat music Modern. Musik pada suasana cerita yang akan dicapai, maka penggunaan alat musik secara terperinci adalah suasana sedih pada dialog didominasi penggunaan biola, bansi, sarunai, saluang dan vocal sedangkan suasana gembira didominisasi oleh penggunaan gendang dan alat pendukung lainnya.

Karya teater Perempuan Minang Merantau berangkat dari fenomena sosial budaya masyarakat Minangkabau dan juga menggunakan idiom Minangkabau itu sendiri. Karya ini dibagi menjadi 4 (empat) adegan dengan deskripsi sebagai berikut:

\section{A. Adegan Pertama, terdiri dari 3 peristiwa}

Peristiwa pertama, Musik pembuka dengan bunyi tepuk tangan seperti mengeluarkan bunyi hep, ta, ti, es seperi orang menggore dalam randai, hal ini menggambarkan bahwasanya pertunjukan akan dimulai. Kemudian muncul tiga orang perempuan dengan gerakan tari randai sambil sambil mengeluarkan dialog, dialog perempuan pertama: aianyo janiah, ikannyo jinak, buminyo dingin, ini menggambarkan luhak Tanah Datar, perempuan kedua: aianyo karuah, ikannyo lia, buminyo angek, ini menggambarkan luhak Agam, perempuan ketiga: aianyo manih, ikannyo banyak, buminyo tawa, ini menggambarkan luhak Limo Puluah Kota. Peristiwa ini mengisahkankan tentang terjadinya luhak yang tingga di Minangkabau, yaitu luhak Tanah Datar, luhak Agam dan luhak Lima Puluh Kota.

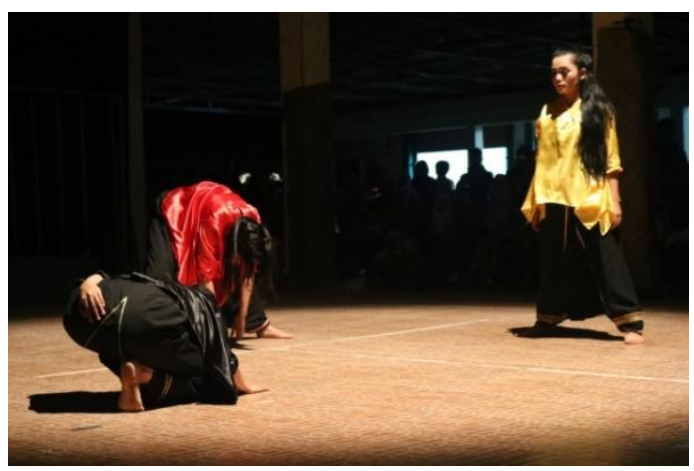

Peristiwa kedua, Seorang perempuan melakukan gerakan dengan property yang dia pegang, menggambarkan peristiwa tentang pekerjaan yang dilakukan perempuan Minangkabau dalam kehidupannya sehari-hari, seperti mencuci, memasak, menjahit/menenun kain, kesawah, keladang dan merawat rumah gadang.

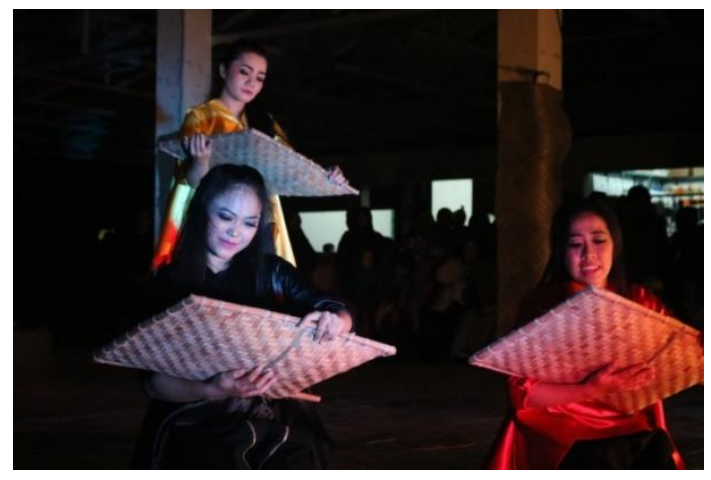

Peristiwa ketiga, Seorang perempuan sedang gelisah dengan ijazah sarjana yang ia punya untuk mencari kerja, setiap melamar pekerjaan selalu ditolak.

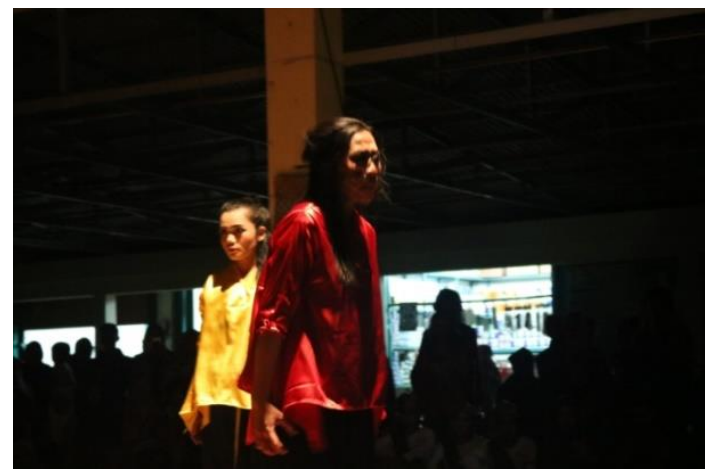

\section{B. Adegan kedua}

Seorang kemenakan perempuan minta izin kepada mamak untuk pergi merantau, yang mana seorang mamak tidak member izin.

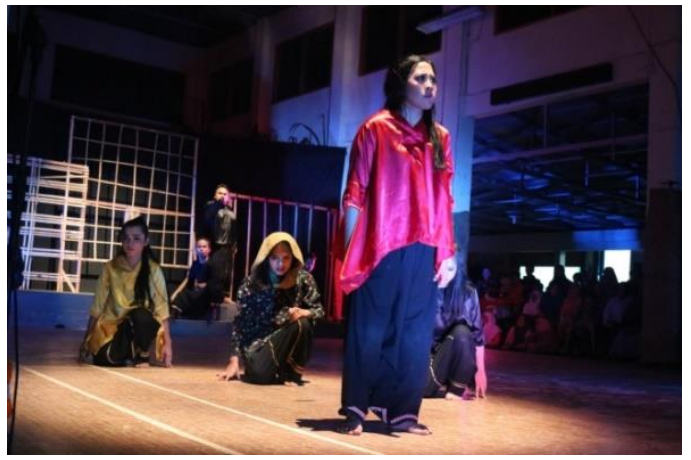

C. Adegan ketiga

Persoalan harta pusaka dan rumah gadang yang akan dijual sama perempuan adik dari mamak yang pingin juga pergi merantau ketempat anak perempuannya merantau. 


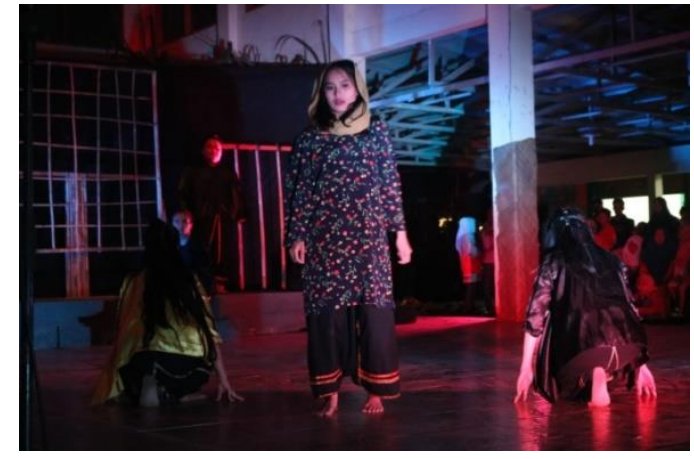

D. Adegan keempat

Penyelesaian dari naskah, penyelesaian ini sekaligus memberikan kesimpulan atas rangkaian peristiwa yang terjadi antara mamak dan kemenakan perempuan yang pergi merantau.

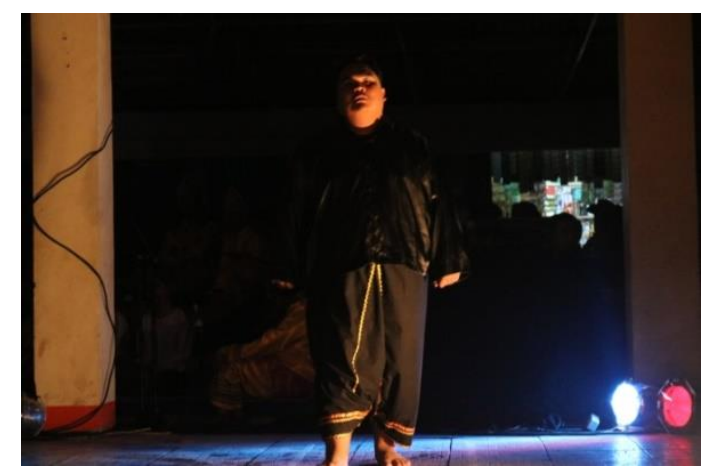

Gagasan pertunjukan teater yang bersumber dan terinspirasi dari fenomena sosial budaya suatu masyarakat perlu dilakukan observasi, agar pertunjukan yang dibuat tidak terkesan mengada-ada dan dibuat-buat atau bahkan menggurui penonton. Pertunjukan Perempuan Minang Merantau ini berangkat dari fenomena sosial budaya Minangkabau, yang terkenal dengan sistem sosial matrilineal. Walaupun penulis lahir dan besar di Minangkabau tapi masih ada hal-hal yang belum diketahui tentang budaya Minangkabau itu sendiri, sehingga dibutuhkan riset dan telaah lebih agar pertunjukan ini mendapat tempat dan pembelajaran untuk masyarakat Minangkabau khusus bagi perempuan Minangkabau yang merantau dan secara umum bagi masyarakat Minangkabau yang berada dirantau.

Perwujudan naskah keatas panggung tidak terlepas dari peran sutradara dalam mengkordinir dan mengatur kerja artistik, baik pemain, pemusik, penata setting, ligting dan kostum. Dalam pertunjukan Perempuan Minang Merantau ini sutradara bertanggung jawab menyatukan tiga kategori yaitu sebagai, penemu, penafsir dan juga penyaji.

Cara sutradara dalam penciptaan teater Perempuan Minang Merantau, ini di awali dari ide/gagasan samapi pada perwujudan pentas, karena dalam proses pencitaan Perempuan Minang Merantau berawal dari: (1) sebuah ide yang diilhami oleh fenomena sosial budaya masyarakat Minangkabau hari ini, (2) menafsir kembali naskah yang sudah ditulis, (3) mempresentasikan rencana kreatif kepada seluruh pendukung karya, (4) melatih pemain dan menggabungkan segala unsur artistik hingga menjadi sabuah pertunjukan yang utuh.

Tata cahaya dalam pertunjukan Perempuan Minang Merantau menggunakan lampu focus pada pemain atau properti dan setting yang digiunakan. Hal ini disesuaikan dengan suasana peristiwa yang terjadi dalam pertunjukkan, agar mampu memberikan efek psikologi pemain dan membantu mood pada pemaian dalam membangun penajaman karakternya.

Tata rias dalam pertunjukan Perempuan Minang Merantau menggunakan rias karakter yang berfungsi untuk memperjelas watak dan karakter pemain. Tata busana dalam pertunjukan inipun untuk menandakan karakter seorang tokoh. Tokoh yang dihadirkan dalam pertunjukan Perempuan Minang Merantau berbicara tentang pergeseran peran perempuan Minangkabau yang biasanya penghuni rumah gadang sekarang pergi merantau, dengan perginya perempuan Minangkabau merantau kenegeri orang maka harta pusaka tinggi dan harta pusaka rendah tidak ada lagi yang mempergunakannya untuk becocok tanam kesawah dan keladang, sudah bertukar fungsi menjadi perumnas dan gedung-gedung pencakar langit.

Kostum juga dipergunakan untuk kepentingan pementasan, kostum juga mempertegas karakter dan latar sosial tokoh. Corak akan memberikan kesan yang jelas dari karakter yang dibawakan. Pada pertunjukan ini semua pemain memakai kostum celana galembong.

\section{Kesimpulan}

Karya Perempuan Minang Merantau berbicara tentang pergeseran peran perempuan Minangkabau yang biasanya penghuni rumah gadang sekarang pergi merantau, dengan perginya perempuan Minangkabau merantau kenegeri orang maka harta pusaka tinggi dan harta pusaka rendah tidak ada lagi yang menjaga dan mempergunakannya untuk becocok tanam kesawah dan keladang, sudah bertukar fungsi menjadi perumnas dan gedung-gedung pencakar langit.

\section{Daftar Pustaka}

Anirin, Suyatna. 2002. Menjadi sutradara, STSI Pres Bandung, Bandung,

Yudiaryani. 2002. Panggung Teater Dunia: perkembangan dan perubahan konvensi seni tetaer, Yogyakarta: pustaka gondho suli.

A. Kasim Ahmad. 2006. "mengenal teater tradisional di Indonesia'. Mengungkap sejarah dan asal mula teater tradisional.

Edwar Jamaris. 2002. Pengantar Sastra Rakyat Minangkabau. Jakrta: Yayasan Obor Indonesia.

DR. Mochtar Naim, Merantau Pola Migrasi Suku Minangkabau.

Amir M, Adat Minangkabau Pola Dan Tujuan Hidup Orang Minang. 